\title{
Codes and Standards Gap Analysis Helps DOE Define Research Priorities
}

\author{
Team: Chad Blake, William Buttner, Angela Costanzo, and Carl Rivkin, Hydrogen Technologies \& Systems Center
}

\begin{abstract}
Accomplishment: NREL researchers analyzed the gaps in codes and standards for alternative vehicle fuels and recommended actions to fill these gaps and accelerate use of the fuels to significant scale in the United States (first reported in January 2010).
\end{abstract}

Context: In October 2008, the U.S. Department of Energy's (DOE's) Codes and Standards activity transferred from the Hydrogen, Fuel Cells, and Infrastructure Technologies Program to the Vehicle Technologies Program, which is responsible for alternative vehicle fuels. The Vehicle Technologies Program includes six alternative fuels: biodiesel, compressed natural gas (CNG), electricity, ethanol, hydrogen, and propane. NREL's Codes and Standards team, which had previously focused solely on hydrogen, analyzed the gaps in codes and standards for these six alternative fuels and determined ways to fill in the gaps with applied research and development.

Codes and Standards Gap Analysis: Organized by fuel type, the codes and standards gap analysis includes one section per fuel with background information, codes and standards citations, and codes and standards gaps. The analysis also contains an appendix of electric vehicle codes and standards.

The team interviewed experts in all six alternative fuels, including representatives from code-development organizations, industry, and other NREL technical experts. The team then used its knowledge and experience to define the gaps and their importance. The six fuels fell into three rough codes and standards groups. Hydrogen and electricity are emerging fuels that require the most codes and standards development work. The codes and standards development efforts required to implement these two fuels do have some common ground, specifically hydrogen safety concerns in battery-charging operations. Ethanol and biodiesel have been addressed in codes and standards through the extensive and well-established requirements for flammable and combustible liquids. They are classified according to their vapor pressure, and once they are classified, requirements are set. CNG has fairly well-established requirements. The codes and standards issues of concern, particularly component maintenance and system maintenance, are those seen with a fuel that is further along in its commercialization than electricity (for vehicles) and hydrogen. Propane has the longest use history, and the major codes and standards issues have been addressed. An excerpt of the executive summary table showing codes and standards gaps by fuel is shown above.

Significance of Accomplishment: The gap analysis showed that the two alternative fuels with the greatest need for codes and standards development are hydrogen and electricity. For hydrogen, the key topics that require work include hazards with high-pressure systems, education outreach to code officials and project developers, improved sensor performance and application information, more testing and possibly additional standards for tanks used on forklifts, and more work on evaluating hydrogen behavior in partially confined spaces. For electricity, the key topics that require work include codes and permitting and approval of electric vehicle charging stations.

Based on this gap analysis, DOE tasked NREL to perform a similar analysis for fuel cell technologies, which will be completed in FY10. 